\title{
World Turned Upside Down: Entrepreneurial Decline, Its Reluctant Myths and Troubling Realities
}

\author{
Philip Cooke \\ Mohn Center for Innovation \& Regional Development, N-5020 Bergen, Norway; cookepn@cardiff.ac.uk
}

Received: 6 March 2019; Accepted: 26 March 2019; Published: 9 April 2019

\begin{abstract}
The aim of this paper is to attempt to understand why the popular academic and policy field of promoting, studying and evangelising "entrepreneurship" should have been associated with great success but, in the past twenty years or more in many advanced economies, so much failure. From the US to lesser and developing countries, emerging economies and the European Union, entrepreneurship, especially in regard to start-ups and particularly high-tech start-ups, has been in constant more or less recent decline. This is seldom registered in the mainstream literature where a positive and benign profile is generally presented. The paper examines this phenomenon, ties it partly with the "productivity paradox" and seeks tentative hypotheses in relation to the apparent illusions if not delusions regarding "entrepreneurship".
\end{abstract}

Keywords: entrepreneurship; start-ups; business dynamics; decline; productivity paradox

\section{Introduction}

In the Michael Moore film Fahrenheit 11/9 the director quotes the Gross's book [1] Friendly Fascism (1980) to the effect that " ... 21st. century fascism will come with a smiley face and a TV show". The show is "The Apprentice", Moore continues: "It was that TV show that made Trump a beloved figure in the United States. People loved watching The Apprentice. People liked the show, it was a popular show". To say the least it is remarkable and somewhat disconcerting that a reality TV show and its anchor-person could have popularised entrepreneurship in the US and other advanced economies, notably the UK, to the extent it has. While further, it enabled the world's leading superpower and democracy to have elected the same TV anchor to the position of president of the US as a by-product. This testifies to something eerie, even unreal, about the mood of contemporary "reality" TV audiences which seem to veer towards something scarily totalitarian in their popular preferences. It also acts as something of a comfort to viewers brought up on the mythology of "the American Dream" of untold wealth in exchange for hard work and a bit of luck. For the stubborn reality is, for most, just that, a piece of mythology, which is little compensation for a hard-scrabble existence on less than two or even three living wages per head of household, deindustrialised neighbourhoods and the prospect of opiate-addiction or worse as the only way out. This paper is a critical review of literature that supports the view that entrepreneurship is thriving. The review shows that it is mostly declining.

These rather depressing sentiments call to mind certain imaginaries of the science fiction writers, some of whose insights seem more and more prescient as time passes. I have called in the past upon William Gibson, but on this occasion, it is some thoughts of Philip K. Dick that infuse the narrative at occasional points, such as this one (prefiguring recently deceased screenwriter William Goldman: "No-one knows anything").

... . . Can any of us fix anything? No. None of us can do that. We're specialized. Each one of us has his own line, his own work. I understand my work, you understand yours. The tendency in evolution is toward greater and greater specialization. Man's society is an 
ecology that forces adaptation to it. Continued complexity makes it impossible for us to know anything outside our own personal field-I can't follow the work of the man sitting at the next desk over from me. Too much knowledge has piled up in each field. And there are too many fields. [2]

In this contribution, I will expose the myth of "The Apprentice" as largely fantasy, delusional and properly suited to the sphere of popular entertainment. This is despite the widespread popularity of the idea and perceived practice of "entrepreneurship" in politics, higher education (notably Business Schools, knowledge transfer departments and some engineering schools), and many other institutional spheres where "absence of entrepreneurial spirit" and "entrepreneurial ecosystems" are bemoaned amid calls for more to be done to kindle, stimulate and foster even further the "business dynamics" of the economy where so much economic development faith has been placed.

This may all come as a heretical and disagreeable shock to audiences in business management and entrepreneurship, also innovation conferences where these beliefs have long held the platform. But the reality of the literature reviewed here, and which has been growing slowly for a few years is that "business dynamics" are generally not in good condition, small-firm performance has of late been underwhelming, start-up businesses are drying up and entrepreneurship data, in general, have registered substantially declining profiles, not just in relatively recent times, e.g., after the financial crash of 2008, but well before, even back to the 1990s which now seem like a relatively "golden age". So, the paper begins with an anatomy of entrepreneurial decline in what is conventionally thought to be the home of "rugged entrepreneurship" in the US. This is followed by selected sketches of the same phenomena described for other advanced or developing economies. The second section of this paper then takes a deep dive into the complex explanations that have been advanced for possible hypotheses as to why "business dynamics" entered decline over twenty years ago in-mainly-the US where most analysis has been performed. Then finally, a comparison of selected advanced economy "business dynamics" profiles are performed in an attempt to tease out reasonable contributory factors to the drying up of entrepreneurship. As will be understood, at various points in the narratives of these three sections the implications for the "productivity paradox" are drawn. As a Review Paper, this is non-experimental, so the Research Design involves detailed critical reading of the "Business Dynamics" literature as the main Research Method. The findings of the Review of the literature comprise the content of the contribution. This is followed by a brief concluding section which summarises the main results.

\section{World Turned Turtle Again}

This saying denotes a major set of events has occurred that has overturned major structures, institutions and assumptions that offer a frame or underpinning to the reality most people take for granted. These things change slowly, un-noticed by most people but as more people pay attention change speeds up. The "conventional wisdom" [3] begins to shrink and uncertainty starts to become prevailing as new certainties to replace the old assumptions are sought, even desperately. Many commentators think that the current era is one of those "transition points" with characteristics of uncertainty, retreat to attitudinal atavism and xenophobia, fears of a "new dark age" and millenarian expectations of "the end times" [4,5]. Relatively few are those persons who keep their antennae attuned to signals of societal change. One small subset of the population which does is the community of science fiction writers, one of whom provides an explanation for our neglect through distraction at the complexity of everyday life, which means we are slow to anticipate change. A representative viewpoint from science fiction literature regarding our "metathesiophobia" (morbid fear of change) is provided by Philip K. Dick:

My major preoccupation is the question, 'What is reality?' Many of my stories and novels deal with psychotic states ... by which I can present the concept of a multiverse rather than 
a universe. Music and sociology are themes in my novels, also radical political trends; in particular I've written about fascism and my fear of it. [6]

Accordingly, most "realities" are rather delayed, sometimes excessively, sometimes marginally. Indeed a workable definition of entrepreneurship could be: "the swift appreciation of changing times ... and spaces". Schumpeter [7] now, sadly, seen more as a harbinger of neoliberalism than social democratic progress, usefully encapsulated the conceptual difference between the "innovator", the "entrepreneur", responsible for the initial investment, growth and employment in key markets, and the "imitator", a different entrepreneur-possibly corporate-responsible for the diffusion and profitable exploitation of the innovation at scale. His later fear [8] was that the facilitating entrepreneur would be squeezed out of the whole process of corporate "entrepreneurship". Acceleratingly, if not for the first time, Schumpeter's wisdom was periodically questioned: first, corporate growth seemed to have extinguished the inventor-innovator-entrepreneur trifecta as spatial divisions of labour evolved with geographical separation of management and innovation (including R\&D) from production engineering and, finally, routine assembly. But then came "lean production" which hollowed-out much of the unaffordable management strata, innovation research, and prototyping, and consigned it to small and medium-sized if not "entrepreneurial" stand-alone firms. So, entrepreneurship revived, especially when science-based start-ups in ICT, biotech and knowledge-intensive services joined them in force while traditional large corporates continued to downsize and/or translocate or both. It took a predictable delay while entrepreneurship scholars imaged up the rugged individualism of the independent entrepreneurs that outfoxed the incumbent corporates (Microsoft cf. IBM; MCI and Verizon cf. AT\&T; Apple cf. DEC, Wang, Amdahl and Prime, etc.). But anyway, this rather atomised version of the Neo-Schumpeterian entrepreneur prevailed until quite recently, when, second, Schumpeter Mark 1 had been reincarnated but also shown not to have got the innovation narrative quite correctly. Thus with the discovery of apparently "social democratic" SMEs colluding in "entrepreneurial ecosystems" [9], Schumpeter Mark 2 corporate "occupational communities" were now to be conceived not as modern innovators but lazy "rent-seekers" [10]. It was as if Philip K. Dick's other 1975 prophecy had materialised on the page.

"A human being without the proper empathy or feeling is the same as an android built so as to lack it, either by design or mistake. We mean, basically, someone who does not care about the fate which his fellow living creatures fall victim to; he stands detached, a spectator, acting out by his indifference to John Donne's theorem that "No man is an island", (sic) but giving that theorem a twist: that which is a mental and a moral island is not a man." [11]

Rational economic "man" was now to be seen as a collaborative, co-operative, subsidised, supported, needy and collectively-minded member of an "ecosystem" rather than a cowboy smoking a Marlboro. Such social phenomena had been researched, studied and written-up since the time of Schumpeter's schooldays by the likes of Marshall [12] describing "industrial districts" (IDs) and later by Becattini [13] in their Italian ID variant before giving rise to the "cluster craze" fomented by regional scientists, planners and Porter [14]. This, in retrospect, may have been the "canary in the coalmine" where planner foresight detected something amiss with an SME world that was beginning to shed its Marlboro Man image earlier than had been spotted by other interested parties. System entrepreneurship signified that individualistic entrepreneurship may have become harder to perform than textbook accounts had suggested and that entrepreneurship scholars had been examining for several decades.

The shock that has yet to be appreciated or, perhaps, rendered subject to metathesiophobia is that belatedly, Schumpeter's [8] thesis of the demise of the entrepreneur has begun. Chronologically later than he predicted and accompanied by the demise of the large corporate entity as an innovative actor, which he had not predicted. Both the typical SME of entrepreneurial lore and the corporate giant of earlier days and more recent examples arising from the Information Age technologies of the 1970 s and the 1990s are no longer replacing themselves as innovators. In the latter case they are often now written-up as rent-seekers while in the former case they are observable from recent data to be a 
dying breed. This is a worldwide phenomenon and no more evident than in the modern homeland of entrepreneurship, the USA.

In what follows, we start a review of comparative SME growth (or decline) performance that covers the financial crash interlude but in many cases takes the timeline from earlier as well as later. Further on, more evidence from a few key economies will be explored more deeply to test this rather startling observation on declining high-tech start-up business dynamics. These will be presented as having declined substantially in the US and various other advanced economies like Canada and the UK since the Great Crash of 2008 and even in some cases before then, dating at least from 2000, some being more affected since 2008 and thereafter up to even the year 2017 in the case of the UK. Many countries had varying fortunes but, in general, business dynamics, notably for high-tech start-ups, declined widely in Canada, Belgium, Brazil, Costa Rica, Japan, New Zealand and Norway joining the UK in an OECD (2017) [15] study of start-ups growth - meaning fluctuating, i.e., mainly declining high-tech start-up rates. The UK findings in OECD (2017) [15] "Business Dynamics and Productivity" show that the distinctive feature of the global financial crisis was a collapse in business entries (new start-ups) which negatively affected the stock of continuing firms in the following year, leading to job destruction. The relative absence of startups halted the emergence of continuing firms.

For New Zealand, analysis throughout the 2000s shows marked decline in worker flows within the labour market and retention of established small firms but with little clear comparison of job-growth from start-up rate increase. Heterogeneity characterises SME performance in Costa Rica. There, agricultural and manufacturing SMEs are in decline while services firms perform better, especially those in export markets or located in Free Trade Zones. In Canada, as we shall see further below, median firm SME growth stagnated in relation to employment, sales, profits and productivity. Norway suffered declining productivity but growing employment from 2000 onwards because of high entry of start-ups in services which were nevertheless relatively unproductive. Services (wholesale and retail) and, surprisingly ICT, contributed to declining productivity performance while manufacturing lost employment. These job losses were mainly accounted for by large, increasingly productive firms whose declining employment outnumbered employment growth from start-ups. Finally, Japan's SME employment growth and numbers either stagnated for the last twenty years or did not recover while productivity declined after the crisis but showed signs of upturns afterwards. Crisis impacts occurred universally across sectors due to labour re-allocation across industries. Accordingly, none of the OECD comparators in this study seem to have performed well in terms of business dynamics after the crisis but in many cases they were already slowing down in that respect before 2008 .

\section{3. "The American Dream Is Now Only a Myth"}

The quote for this section heading comes from Stiglitz [16]. It was suggested earlier that other research literature by the likes of Gordon [17], Erixon and Weigel [18], and Lindsey and Teles [19] points to corporate "rent-seeking" having displaced innovation (Schumpeter 2's miscalculation). If so, and leading high-tech social media behemoths also "hollow-out" their own as well as their clients' workforces, past practice has often shown the SME sector taking up the slack regarding job growth. Except that the latest evidence suggests the contrary. In this section of the paper we review the evidence for this-i.e., that high-tech start-ups have declined as sources of US job-growth. One reason for this focus is that there is a deeper, time-series base for the phenomenon in the "business dynamics" literature for the US. In the succeeding (fourth) section of the paper we shall try to review and assess if the process is also pronounced in other economies such as the UK, Canada and selected European and Asian countries.

Regarding US evidence, the post-2000 decline in US high-growth young businesses in key innovative sectors like high tech suggests there has been a decline in transformational entrepreneurs in this sector. There are many detailed research studies reported in the following citations, with some guidance in the text on the nuances of each. Why this decline has occurred is an open question [20-24]. In the post-2000 period, high tech includes fewer young firms, and the young firms that are present 
are less likely to have high growth [25-27]. As noted above, this period of decline in high-growth entrepreneurship in high tech coincides with the decline in aggregate productivity growth in the high tech sectors of the economy as documented by Fernald [28]. Given the important role high-growth young businesses have played historically in the US, especially in sectors like high tech, understanding the causes and consequences of this decline should be a high priority for future research. For some time, the sector has been buoyant in UK and elsewhere in Europe but technological job-decline has been registered in China and elsewhere in Asia. Now recent evidence suggests an entrepreneurship plateau dipped down in 2017 in the UK and declined even earlier in Belgium [29,30].

We start with Hathaway and Litan's study [27]. The authors quote copious research by authors like Decker, Haltwanger and others cited above that show that start-up activity declined in the US across every sector of the economy including high tech since 2000. This also applies to every state and metropolitan area where, typically, start-ups used to be responsible for the majority of employment growth. US entrepreneurship has clearly gone into reverse. The assessment that only $20 \%$ of the workforce is now employed in firms born after the mid-1990s is surprising given the hype about entrepreneurship and the widespread belief that many household name businesses were created in the last decade alone. But it seems that the few fabled gigafirms in high tech like Facebook, Google and lesser ones like PayPal, Tesla, Netflix and so on, alongside older firms in heralded industries like biotechnology, are either very few but prominent if they reach a large scale or get acquired and absorbed into older high-tech firms, or fade away in some other absorption or death spiral manner. In passing, it is instructive that investment in healthcare acquisitions by FAGAMi (Facebook, Apple, Google, Amazon \& Microsoft) alone rose from $\$ 270$ million to $\$ 2.7$ billion in the eleven months to November 2017. Apple (Figure 1) has added substantially to its one hundred-strong list of start-up acquisitions in varieties of ICT and nowadays, artificial intelligence (AI) by adding half a dozen healthcare start-ups to its recent acquisitions portfolio. This is emulated by Google, IBM and FB who are all engaged in "cognitive computing" (IBM) or varieties of machine learning (FB) or deep learning (Google acquisition of DeepMind) for application in the new field of AI healthcare. The graphic of Apple's "healthcare plan" is meant simply as downloadable illustrative material, which readers can replicate for other Big Tech companies listed in the previous sentence. The point is that one explanation for decline in entrepreneurship is that founders are "selling-out" to Big Tech, thus denuding the start-up "gene pool".

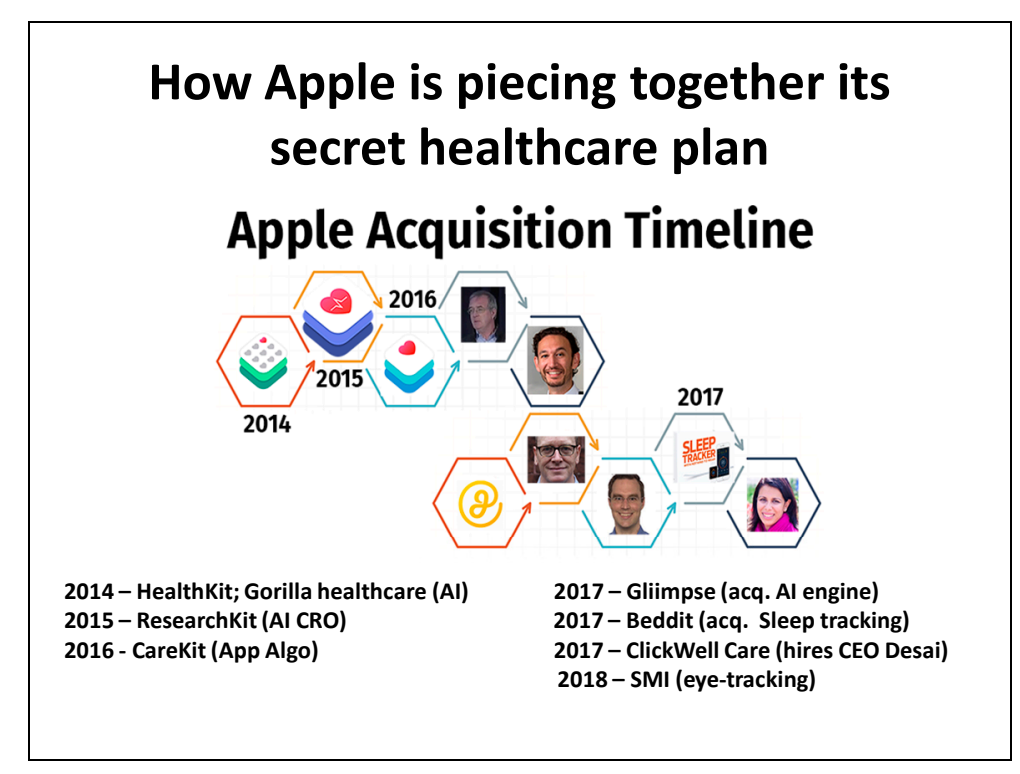

Figure 1. How Apple is piecing together its secret healthcare plan. 
The earlier point about only $20 \%$ of employment being accounted for by start-ups dating from after the mid-1990s is underlined by the observation of Aldrick [31,32]) that even since the 1980s the US rate of new company formation fell by $40 \%$. Further, a sector that employed $20 \%$ of the workforce in 1988 and which also accounted for 70\% of gross job creation between 1992 and 2011, by 2018 only accounted for $10 \%$. Commentators from former Federal Reserve Chairwoman Janet Yellen that " ... the dynamism of the US economy has diminished" to Nobel Laureate and former World Bank chief economist Joseph Stiglitz's view that "The American Dream is really a myth. We like to think of our economy as being dynamic, new people creating new firms. The data say we are becoming less dynamic" testify to the new US reality on entrepreneurship. The implication that large firms are "taking up the slack" warrants further exploration in this piece.

Thus record low unemployment, hovering below 4\% since April 2018 seems to support Aldrick's contention. However, a major reason why not is that the workforce in general has also been in decline. Accordingly, the US workforce was falling by some 235,000 per month in 2018 . Labour force participation fell to stagnating at around 63\% since 2015 (Figure 2). To underline and repeat the point of Figure 2, it shows the workforce employed or seeking work in the US to be in decline, meaning another force diminishing the population among which it can be hypothesised many routine or even highly-skilled entrepreneurs may have been lost. As clarified at the end of this paragraph, as well as being victims of "discouraged worker syndrome" among the higher-skilled population of the unregistered unemployed (perhaps due to automation of work) the loss of potential entrepreneurs among the lower-skilled used to be a significant source of start-up business activity. They may also have become "technologically unemployed by automation of work" in some accounts of the decline in "business dynamics". Both are now part of the more general entrepreneurial decline. This includes a substantial "discouraged worker" element in the US population, leaving an historically low recent labour market participation rate, which was once picked up by start-ups, but no longer. So, to conclude this momentary diversion into the "double-whammy" experienced by the US economy of large-firm job loss and a precipitate decline in start-ups in recent years, what are the causes? Business economists seem to be guided more by ideology than research evidence, choosing the only indicators that match their political preferences. Right-wingers blame over-regulation and education policy while left-wingers blame corporate tax-cuts and "financialisation" which favours mergers, rent-seeking and structured finance rather than financing enterprise. Wherever the answer lies, the large firm-small firm contraction shows up in low productivity performance. Hitherto, productivity increases were assumed to be the product of start-ups and entrepreneurship because large firms had become, at best, imitators of SME innovations rather than innovators in their own right-see, again, Erixon and Weigel [18]; Lindsey and Teles [19]. But now, with the start-up data showing declining "business dynamism" it is likely that a major part of the "productivity paradox" is explained by the absence of innovators in recent times. A further, related contributory factor is that the innovation frontier is now even more highly skill and competence demanding for new graduates. This, too, gathers testimony from the close-to halving in the percentage of graduates who were entrepreneurs from $4.0 \%$ in 1992 compared to $2.2 \%$ in 2017. Coincidentally and not conforming to the received image, Brookings' [33] research shows that many self-employed individuals have relatively low education levels and opt into entrepreneurship as a default rather than choosing it. Accordingly, the self-employed have lower life satisfaction than their wage-earning peers. This contrasts with many prior studies that document a positive relationship between entrepreneurship and life satisfaction. 


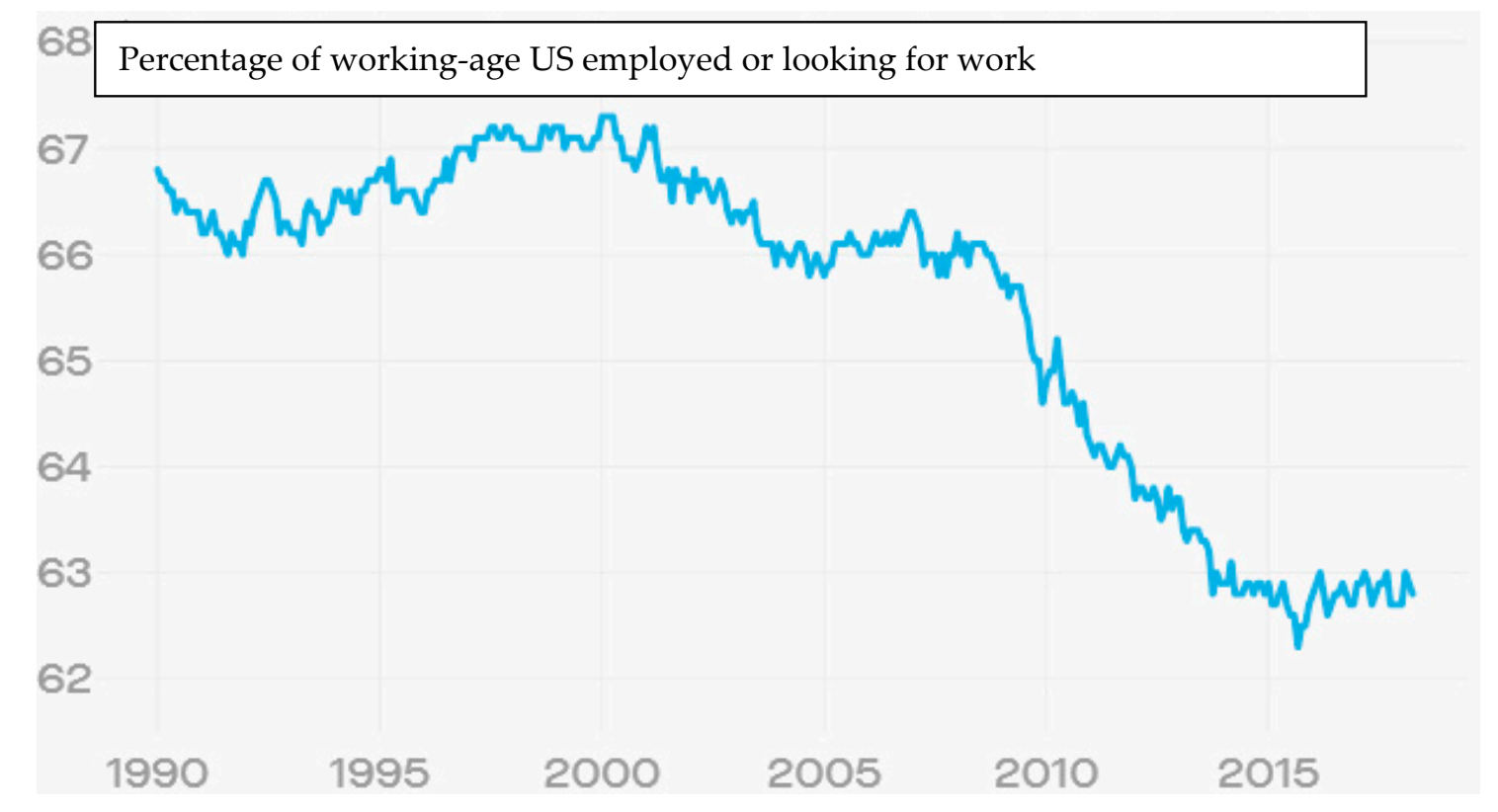

Figure 2. Percent of working-age Americans employed or looking for work. Source: BLS.

Exploring more deeply into the historical record, Hathaway and Litan [27] began with demographics and found that there were close correlations between population change and start-up activity both for the 1980s (before which there was no modern start-up data) and the contemporary period. In simple terms, both periods showed strong demographic effects but also less obvious ones. The analysis was done with regions as the basis for comparison and firms as their unit (not establishments, existing ones being responsible for spawning up to $40 \%$ of new businesses). Predictably the "Sunbelt" regions in the south west and Florida out-performed the north east "Rustbelt" regions. Data for metropolitan city-regions revealed a more intense correlation. This is consistent with two contrasting hypotheses; one is that firm formation rises with the supply of population; the other is that it rises with demand from a rising population. Either way the correlation holds but so, possibly unexpectedly, does the one that shows that high start-up regions decline in firm-formation capacity after about thirty years. So given thirty years of relative start-up quiescence in the Rustbelt, it was joined thirty years after population grew significantly in the Sunbelt, which together accounts for an overall regression to the mean. Further analysis suggests such regression is influenced by "business consolidation" or the aging of regional firms and the erection of evolving barriers to entry by established firms [34]. In combination these correlated modestly but the strongest magnitudes underlying change were the initial start-up rate, subsequent population decline and greatest declines in personal income growth. A local "boom-followed-by-bust" profile predominated in regional start-up declines. This may be what the US firm formation rate is displaying, namely a seemingly immutable secular decline in firm-formation, or if it is preferred, "entrepreneurship".

We now briefly return to the research pointing consistently to the decline in US entrepreneurship in recent years to establish what, if any, plausible hypotheses or putative explanations are offered before, in the final main section of this paper we review the status of entrepreneurship in selected countries and regions. First, let us pay attention to a summary article by the group of researchers into this issue led by Decker et al. [23] starting with their cited paper entitled "The decline of high growth entrepreneurship". They point at the outset to a significant change in high growth entrepreneurship since the 1980s to 1990s when decline was dominated by a dearth of start-ups in the retail trade. By the 2000s though, this profile was replaced by a different segment of the start-up product market with a sharp decline in high-growth young businesses in key innovative sectors like high tech. Clearly there was a marked decline in transformational entrepreneurs in this sector. Their contribution aims to tease out key factors that hypothetically may be considered responsible for this change. 
One question concerns the distinction between "transformational" and "lifestyle" entrepreneurs, the latter conceived as the less "embedded" of the two. Their evidence shows that, while retail predominated in the earlier period, equivalent declines occurred later in the "information" sector of the start-up economy. The authors define high tech as firms with highest concentration of science, technology, engineering and mathematics (STEM) workers to which are added appropriate STEM sub-sectors from ICT manufacturing and scientific services. The data reveal that while sectoral entrepreneurship decline occurred throughout the 1978-2011 period, information start-ups grew most in the period leading up to 2000 but declined at exactly the same rate as retail after the "dot.com" slump thereafter-specifically booming and slumping 1997-2005. High tech thus displays more "skewness" than retail because it had a predominance of young start-up entrepreneurs, many of whose firms disappeared in the slump while retail firm start-ups were not characterised by such a youthful cohort of start-up entrepreneurs but ended up with a similar downward trajectory nevertheless. A key question, apart from the obvious "shakeout" effects of the dot.com slump is why did both these demographically and skills-profile sectors reach the same downward destination? The evidence mainly points to fewer young high-growth start-ups in retail than in ICT. The authors also determine that the post-2000 period shows a decline in transformational entrepreneurship, at least as measured by employment growth. There was also a common rate of decline in business dynamism in all sectors. This points to a decline in high-growth young firm activity although it is unclear if causality is more singular than multiple, with sector-specific implications. For example, research shows that retail trade entrepreneurship decline is largely an effect of displacement of SMEs by large national chains that were more competitive through enhanced productivity. In passing, they in turn are outcompeted in 2018-onwards by online retail as practised with devastating effect on the likes of Sears (also mall chains like Abercrombie \& Fitch, American Apparel, Best Buy, Gap, J. Crew, Kenneth Cole, Macy's, Radio Shack, Rockport, Toys ' $R$ ' Us, The Limited, and Urban Outfitters) by competition from Amazon. A further feature of the convergence of decline in business dynamics between retail and high tech is that in the post-2000 period while high tech includes fewer young firms, it is also the case they are less likely to have high growth. This period of decline in high-growth entrepreneurship in high tech coincides with the decline in aggregate productivity growth in the high-tech sector more generally as documented by Fernald [28].

The evidence here for IT productivity is that it declined before the Great Crash or Recession of 2008. This in turn was caused by the slowdown both in industries producing and using IT intensively. While capital deepening, labour quality and total factor productivity grew at rates unforeseen since the 1945-1973 era, the dot.com boom was shortlived and pervasive as IT took on the character of a general purpose technology (GPT) after Helpman [35] it took a Solow residual (or paradox) interlude for it to be absorbed fully into the IT productivity statistics as indicated in a belated, marked increase in labour quality around 2007-2013. The low-hanging IT fruit had been plucked by 2005 but could not be digested much until nearly a decade later. The slowdown heralded a lower GDP growth rate and associated lower gross investment rates leading to lower utilisation and associated innovation demand that might otherwise have stimulated entrepreneurship, pari passu. This is evidently well-identifiable in the contribution to IT entrepreneurship from its adoption and eventual utilisation in the retail trade. Even though it is argued by many, including Fernald [28] that entrepreneurship started to decline early in the twenty-first century, Fort et al. [36] also show that young and small firms, already particularly sensitive to fluctuations in housing prices through a range of credit channels, meant that start-ups were hit hard during and since the Great Recession. So there is now evidence that high-tech entrepreneurship was already in decline before but then exacerbated even more by the global financial crisis of 2008 and afterwards.

So there is broad agreement on the underlying narrative of the story that turned the assumptions of those who see an entrepreneurial growth profile in the current and foreseeable economic era in the USA. It is roughly as follows. To the contrary, observable rates of start-up activity, new firm entry and job creation have trended steadily down over the past 1984-2014 period with notable further declines since the Great Recession. Theorised or believed dynamism is good for politicians and other mythologists 
because it is comforting to feel their beliefs are associated with benign economic outcomes represented in redistributive growth trajectories realised through society's improved innovation performance as implemented through new firm formation by entrepreneurship. As we have seen for the US case, the existing "business dynamics" literature does not support this benign view and does not clearly or incontrovertibly establish why business dynamism has declined. More research is, for example, needed into the extent an aging population could be influential by fomenting a more risk averse innovative population cohort. Some on the right have argued that increasing regulation could have raised the cost of business entry, but in a deregulated "neoliberal" era that seems almost bizarre in principle. Even worse is any evidence that innovation may have moved back into large established firms when all the evidence points to them having become classic, parasitic rent-seeking corporations as discussed earlier. On the other hand, the acquisition process by which large corporate rent-seeking practices stifle entrepreneurship are well-worth detailed examination. We have pointed to the way the rent-seekers cherry-pick the specialist innovators in their fields of operation, which are nowadays many and involve inter-sectoral knowledge crossovers, in order to penetrate relatively under-exploited market potential in legacy quasi-markets like healthcare, education and defence. This creates a chilling effect more than a re-heating of innovatory spirits among firms for whom monopoly always outweighs competition [34]. So, there has been relatively little by way of a "surge" in entrepreneurship in recent years, except for the brief three years around the turn of the millennium, with that largely confined to the IT sector in the shortlived dot.com boom that heralded a succeeding, long high-tech slump.

\section{Rule One: Never Tell Your Superior Something He Doesn't Want to Hear}

This simple instruction is given in Dick's [37] The Three Stigmata of Palmer Eldritch, Garden City NY, Doubleday. Academic research is different from science fiction because it generally ignores that Rule. It must follow a different one, associated with Thomas Jefferson about "speaking truth to power". Yet today, speaking truth to power sometimes requires a courageous act. Why? Because you may not be clear in whose "truth bubble" or "which hat your superior is wearing" at any given point in time. So if the public academic makes a legitimate truth claim based on her publicly-funded contract research, she has a duty truthfully to report it doubly through her contract with her (public) employer and with the public funding agency to which her research is contracted. As universities became more semi-privatised or became or were founded privatised, such duties have so far remained unobscured. If a research contract is funded by a private client, its contract will specify the limits (if any) of what your superior does not want to hear. It is increasingly that way in your publicly founded university where you were required to sign a "disclosure agreement" on which your employer may have first ownership call, comparably with any "intellectual property agreement". You may perforce have had to sign one of these by virtue of its likely or possible market value to which your institution may also have a right of ownership. But what if your superior is not only your main employment supervisor but also an appointed member of an executive board of a public agency or, a fortiori, a private one or an independent private firm? Or what if your superior is also a government adviser, or an adviser to a foreign government? All these various combinations of roles are daily experienced by academic researchers in biotechnology and pharmaceuticals research, which is why it is often journalists rather than academics who divulge scandalous evidence to the public while medical researchers pump out articles or interviews about the latest anodyne findings on the virtuous or deleterious effects of red wine or red meat consumption. Social scientists are untrammeled by such constraints because they are far less prey to the interests of Big Pharma, Big Food or Big Tech and its research lures. But it can happen in subtle ways when that article or letter you sent to a newspaper was published and upset the superior when he was advising her or his private retainer whose board was so irked that it critiqued agency performance in some direct or indirect way that your superior was asked to "have a quiet word" with you, and perhaps penalise you in some direct or indirect way in the future. This discourse or narrative may ring bells with readers who have paid attention to the "safeguarding" debate and legal cases or prosecutions arising in the film industry, media and governance arenas since 
2018. "Institutional abuse" remains one of the worst of the remaining barbarities of the "iron cage" of bureaucracy, as Weber termed it.

Coincidentally, (non-) disclosure agreements (NDAs) hit the headlines in the UK in 2018. These were originally introduced to protect IPR when key staff changed jobs to protect information but "legislative creep" means they are used by prodigiously wealthy litigants to prevent scandalous accusations on their personal behaviour being printed by journalists. Hence they are a direct threat to so-called "open democracy". Morgan-Bentley [38] reported that research advisers to UK government departments had had to sign NDAs affecting ministers, their departments and even the prime minister, banning 40 charities and over 300 companies from publicly criticising them in deals costing the taxpayer $£ 25$ billion. Since 2015 some 398 contracts with "adverse publicity" clauses had been signed with adviser firms or contractors. Among the most prominent were US, Dutch and UK consultant advisers to the UK government on Brexit. Boston Consulting Group (BCG) agreed a $£ 2$ million deal with the EU exiting department (Dexeu) beginning in December 2017 and ending in September 2018. The UK Cabinet Office signed an NDA deal with Dutch firm Arcadis for July 2018 to January 2019 worth $£ 239,000$ to support Dexeu on IT. Finally the UK Home Office signed an NDA contract with accountants PWC on EU immigration status for $£ 824,000$ for a year starting in August 2018.

So, academia is also one of those vestigial "iron cages" capable of inflicting barbarous behaviour on its institutional members. This is because academic "crowds" are peculiarly prone to being "strong identifiers". Strong identifiers are the cause of political correctness (PC), virtue signalling, gaslighting, safe spaces and so-called trigger warnings to signpost such. Thus it may be perceived in some readerships that the evidence that entrepreneurship is drying up, that large firms are no longer innovators but rent-seekers, that low unemployment rates conceal large numbers of discouraged workers and that benign performance profiles are nothing but myths are all "politically incorrect" thus unacceptable and untrue. In particular, that narrative contradicts the institutionally abusive hegemony in economics that privileges its neoclassical version:

Neoclassical economics conceptualized agents, households and firms as rational actors. Agents were modeled as optimizers who were led to "better" outcomes. The resulting equilibrium was "best" in the sense that any other allocation of goods and services would leave someone worse off. Thus, the social system in the neoclassical vision was free of irresolvable conflict. The very term "social system" is a measure of the success of neoclassical economics, for the idea of a system, with its interacting components, its variables and parameters and constraints, is the language of mid-nineteenth-century physics. This field of rational mechanics was the model for the neoclassical framework. Agents were like atoms; utility was like energy; utility maximization was like the minimization of potential energy, and so forth. In this way was the rhetoric of successful science linked to the neoclassical theory, and in this way economics became linked to science itself. [39]

Evolutionary economics is constructed with a different framework for economic agents, firms and markets. History, routines, influences of environment and institutions are highlighted far more. This is argued by, for example, Pavitt where firms are specific agents $[40,41]$, which do not behave as "profit maximisers" given the complexity of their environment and conflicts of interest. Agents are thus incapable of computing optimal solutions [42] and even less of forecasting other agents' practices because of uncertainty $[43,44]$, bounded rationality $[45,46]$ and differing expectations $[47,48]$. Thus in evolutionary economics, firms are distinctively organised to use distinctive inputs for what they produce, one of which is knowledge [49]. The constitution of a firm is mediated fundamentally by the founder's knowledge or "creative agent" then developed by learning. Firms learn from their own practice and that of firms they work with and with whom they share information, knowledge and technologies. Firms also have a history, a trajectory of path dependence that guides their development. Firms are founded, they explore and discover new paths of growth, they evolve new routines, formulate technological capabilities, capture new opportunities, adapt to new constraints and competition 
or cannot respond to this demanding entrepreneurial environment and gradually disappear from the market.

The narrative on US "business dynamics" above fits as well if not rather better to the evolutionary than the neoclassical parsings presented above and displays the desirability of both speaking truth to power and telling your (neoclassical) "superior" something he doesn't want to hear, so now, to round off the present monologue we shall briefly examine the evidence regarding any recent decline in "business dynamics" in representative non-US economies. This is attempted to see-although we have been somewhat forewarned-whether declining dynamics is a feature of American exceptionalism or something more protean.

\section{Everything in Life Is Just for a While}

Philip K. Dick wrote this sub-heading in "A Scanner Darkly" (1977) [50] which has a narcotics detective investigating drug crime in a dystopian Orange County, California. The thought, however, has much wider applicability because of the eternal truth that nothing lasts forever. The reader may recall the roll-call of bankrupted or reduced retail firms listed for the US in the recent 2000s. Next in this section a similar story of some 85,000 retail redundancies in the UK for the first nine months of 2018 now features. Regarding entrepreneurship, an annual rate of over 5,000 store closures was reached but store openings for 2018 ran at only some 3,000-plus, leaving store closures significantly outpacing the latter. Online retail by Amazon is a proximate cause but others include uncertainty about Brexit and protectionist tariffs under the influence of the Trump administration's MAGA (make America great again) lessening of trade with Asia, where many textiles suppliers had supplied UK retail discounters [51]. Together with this attenuation of retail entrepreneurship (echoed in our US account above) is a thinning-out of the previous thirty years' period of the World Trade Organisations's "globalisation" strategy. China, for example, is committed to curtail its own "world factory" image and turn towards, on the one hand, boosting domestic consumption, while on the other, accelerating its endogenous technology industry (notably AI and robotics) something Rodrik [52] analyses. Accordingly, it may be proposed that these two mainstays of global trade have only lasted "just for a while".

So, before returning to the UK case, where the high-tech start-up downturn is also shown to be a recent phenomenon, let us look first at the narrative for "business dynamics" in Canada. Here, entrepreneurship is also in decline with both firm entry and exit rates lagging, showing "creative destruction" lifeless in Canada as well as elsewhere. Thus, as in the US, start-up rates and their associated job-growth proclivities have dried up thus affecting productivity. Criscuolo et al. [53] found that, during the 2000s, the share of start-ups (firms less than three years old) declined in many nations, including Canada. Based on a new set of linked, experimental data for the period 1983/1984 to $2011 / 2012$, Canada's business-sector entry rate declined from $24.5 \%$ to $13.1 \%$; and, the exit rate fell from $16.5 \%$ to $11.6 \%$.

However, the evidence supporting, or invalidating, this view is scarce [54]. This suggests that the decline in productivity growth is partly caused by a decline in the productivity-based exit selection process. However, business-cycle measures appear to cause both productivity and the exit rate. This suggests that firm dynamics are an intermediate, not an ultimate, cause of productivity growth. The Canadian data reported in this research show stagnation in business dynamics, measured by lower entry and exit rates, across industries. Entry rates are ascribed more significance than exit rates in relation to Canada's business dynamics decline and associated "productivity paradox".

A Canadian consultancy report [55] concurs with the Bank of Canada opinion but stresses something that crops up later in respect to the UK's declining business dynamics: the prevalence of "zombie" firms. The report is based on a comprehensive study of more than 700 Canadian businesses that analyzed their future-focused attitudes and practices, and builds on previous Deloitte research examining Canadian business culture and productivity. As part of the study, Deloitte also found that $16 \%$ of public companies are considered to be "zombie" companies. That is $60 \%$ higher than the 
global average of $10 \%$ and highlights that many Canadian businesses are in a vulnerable position when it comes to economic shocks and technological disruption. "Zombie" companies are defined by the OECD as mature businesses-aged 10 years and older-whose earnings are not high enough to cover the interest payments on their debts and yet still manage to survive. They are a drag on productivity because they divert capital and talent away from more productive firms and hinder the ability of younger, more dynamic businesses to grow. Sample respondents continued to struggle with the discipline of innovation: just 19\% of survey respondents reported having processes in place to test and scale innovations. Less than half of Canadian organizations reported making the investments in the people and technology they said they need for the future. Finally, only $3.6 \%$ of Canadian companies exported their output.

Moving on, briefly, to an examination of business dynamics in Belgium-taken as a small-medium sized EU Eurozone member-state. In Bijners and Konings' [30] study they utilised a 30-year dataset from all Belgian private firms, and demonstrate that Belgium, too, saw a comparable decline in dynamism to that experienced in the U.S. since 2000. The authors show that fewer small firms became fast or high-growth firms; as in Canada and the U.S. the decline seems secular rather than compositional. Potential generic factors include, once more, the increased use of ICT or the increased participation of emerging economies in global supply chains. The steep increase in globalisation of the past decades has exerted substantial effects on both exporting (unlike Canada) and importing firms.

In general, high-growth firms are responsible for a disproportionate share of overall job creation and productivity growth. While for the U.S., the decline in high-growth firms is especially evident for young firms, Bijners and Konings [30] claim the decline in Belgian high-growth firms is predominantly driven by the decline of high-growth, small firms. The propensity for large, older firms to become high-growth firms seems to be trending upwards while the propensity for a small firm to become a high-growth firm has rapidly declined since 2000. Despite this scissors-effect, the authors found that young firms invested in innovation more per capita than larger firms, suggesting the latter fitted the "rent-seeking" image discussed earlier in this paper as a modern characteristic of corporate business strategy in an age of "financialisation. There seem to be as many contradictions as smooth explanations from the analysis of three decades of Belgian business dynamics: however, the direction of travel does show the same kind of "decline" consistency.

As a penultimate possible "corrective" to our consistent transatlantic comparison, with so far one alone of the Eurozone member-states to confirm our burgeoning picture of entrepreneurial decline, we turn briefly now to Japan to scan the signs of this process for a very different economy thus far. Since the 1990s the Japanese economy has, in general, stagnated with productivity growth in decline across the board, notably in its once-propulsive advanced manufacturing. Stock market listed firms in Japan have performed 25\% worse that equivalent non-financial corporates in the US, a symptom of large-scale misallocation of capital. By 2011 Japanese "advanced manufacturing and consumer electronics had fallen further behind US equivalents by some $70 \%$ and worsening to 2011 . Productivity was also hit by haken, the practice of hiring temporary workers, producing an under-incentivised lower-level dual labour market.

Japan lacks a start-up culture. McKinsey [56] recommends certain measures that are long overdue. Foremost among these are "fostering a startup culture" by, for example incentivising angel investing and varieties of corporate "intrapreneurship". Stimulating inward investors to implant business dynamism is also advocated. Finally creating an ecosystem that allows entrepreneurs and innovation to flourish is crucial according to McKinsey (2015). In summary, Japan offers little by way of guidance out of the maze of underperforming or even dormant entrepreneurship spirit and has yet to throw off its formerly influential corporate structures that now seem to have atrophied.

Finally, the UK has until recently avoided a major decline in its entrepreneurship profile although much of that evolution was a response to the shakeout from many public and private employers and the rise of prodigious numbers of under-employed and barely surviving "zombie" companies created by sole traders managing to survive on historically low interest rates stimulated by quantitative easing 
(comparable to Canada). By approximately 2017, that sticking plaster was beginning to unpeel as the start-up rate for new firms turned down following the artificially boosted "entrepreneurship" of the post-2008 period. This has obviously been exacerbated by the pre-Brexit run-up which has seen record redundancies in retail (as in the US). Accordingly, as indicated above, recent evidence from the United States [20,36] suggested job creation by young firms had been affected the most, while job destruction of young businesses remained virtually unchanged. Similarly, recent evidence from the United Kingdom [57] shows that the crisis was a period of sustained lower job creation, especially for small and medium sized firms. Thus UK start-ups declined 13.7\% in 2017-2018. The government has been accused of failing to look after the interests of small business after the first decline in the number of new companies created in seven years. Figures released by the Centre for Entrepreneurs revealed a 13.7\% decline in the number of start-ups formed in Britain in 2017. The report, using data from Companies House, showed just over 589,000 new ventures created in 2017.

The UK data consulted in Roper and Hart [29] suggests some underlying concerns, however, about future levels of ambition and SMEs' willingness to borrow and invest for future growth. In the 2017 survey, $62 \%$ of SME employers indicated that they planned to grow the turnover of their business over the next three years, the lowest figure since the survey began in $2007 / 2008$. At the same time SME's willingness to seek external finance has also fallen consistently since 2010. Trends in start-up, growth and retrenchment all play an important role in shaping job creation in both gross and net terms and together form a measure of business dynamism in the economy. The number of start-ups in an economy is often seen as the headline metric of 'enterprise' and 'entrepreneurial ability'. Start-ups have been rising steadily in the UK in recent years but have stagnated in 2017. The downturn may have begun even earlier at approximately 2015. Data on SMEs consulted suggest that $28 \%$ of firms intending to increase export sales had scaled back this activity due to Brexit. Similarly, $10 \%$ of SMEs had scaled back plans to develop new products/services and $9 \%$ had reduced capital and R\&D spend. In line with data from other economies profiled, productivity data reveal that only $8.4 \%$ of all employer enterprises in the UK achieved positive productivity gains (revenue per employee) while still increasing jobs over the period 2014-2017. Previous research showed that there was a very poor correlation between jobs growth, increases in revenues and productivity gains. This, of course, underlines the more widely observed phenomenon of "zombie" firms that employ few or often one on survival rations fuelled, perhaps temporarily by redundancy payments from former employers, "gig"-type projects and cheap loans resting upon quantitative easing from central banking institutions (Butler, 2018). Survey estimates suggest that at least 100,000 UK firms fitted the "zombie" characteristic, exerting further downward pressure on productivity.

\section{Conclusions: Unicorn Fantasies and Brexit Zombies}

Entrepreneurship became a hot subject of interest for business schools' case material and enterprise researchers. It is no less a trendy career choice for graduates. Added to this, as we have seen, the credit crunch prompted people to start their own business as the jobs market shrank. Startups were formed at a record pace in the UK until the last year (2017), according to research. But along with the boom in startups there has been a race to the bottom to get investment. As these businesses mature their performance drops off, in part due to a lack of long-term planning [58]. In effect, they become zombie startups, the term for companies that keep going after funding runs out but don't actually grow, and investors no longer see them as attractive or worth a punt. This is overshadowed by press or political lauding the single unicorn that makes it. Moreover, for some time tech startups have also been pitching models that do not generate cash for venture capital firms and angel investors. Rather traditional business plan customer data is trotted out in the hope that one day this data will be valuable. But many investors now demand that the businesses they invest in must generate proper sales to real customers. As Guy Kawasaki, the Silicon Valley investor, declared in chapter 10-The Art of Rainmaking —of his book called "The Art of the Start" "sales fix everything" [59]. 
If the phenomenon of little job-generation from sole-trader start-ups is thus one feature of the drying up of entrepreneurship, another contributory factor concerns entry rates, which seem fairly consistently to explain declining business dynamics across the piece. That is, start-ups in some cases can survive and, at the "unicorn" limit, thrive, but there are relatively fewer of them than there were twenty years ago and they do not create the large workforces of the likes of Amazon, Facebook and Google, to name a few. Thus Amazon's second headquarters, employing 50,000 will be split between Long Island City, New York and the Arlington suburb of Washington DC. Five-thousand more will be located at its "fulfillment centre" consignment hub at Nashville, Tennessee. Amazon's global employment (full and part-time) reached 566,000 in 2017. In 2018 Alphabet (Google's parent firm) employed 94,732 globally, of which Google had 85,050. It is worth noting that unpublished data accessed by D'Onfro [60] suggested Alphabet's outsourced labour exceeded in-house labour for the first time in July 2018. By comparison Facebook's employment was 33,660 in September 2018.

A figure of some 39,000 contract workers was hired in Silicon Valley in 2017 according to a UC Santa Cruz research report cited by Sheng [61]. More broadly, some 57.3 million Americans, or $36 \%$ of the workforce, are now freelancing, revealed a 2017 report by Upwork [61]. So, briefly, such labour-intensive part-time, often short-term recruitment in relatively large numbers means low wage costs for the "flagships" but locally low compensation compared to full-time professional labour and a likely drag effect on both capital and labour productivity. So this is another part of the entrepreneurial decline from labour absorption and, to a marked extent, small-firm acquisitions (for example Apple's "developer ecosystem" has 300,000 contracted apps in its AppStore [62]. Tepper and Hearn [34] estimate that Apple actually outsources to 2 million contractors globally [34].

Finally, business dynamics decline is also specific to the high growth, high-tech sector which had hitherto burgeoned. It had, to some extent, displaced the retail growth sector a little earlier. By the 2000s though, that profile was replaced by a different segment of the start-up product market. This was displayed in a sharp decline in high-growth young businesses in key innovative sectors like high tech. Clearly there was a marked decline in transformational entrepreneurs in this sector. The reasons for this include the weakening opportunity for such entrepreneurship due to the "low hanging fruit" having been picked earlier, demographic decline in the population cohorts with which such start-up growth dynamics were associated and, above all, in the more recent decline in the availability of risk capital associated with the financial crash after 2008. All in all, these multiple causalities contributed in manifold ways to a decline in business dynamism when little such compensating dynamism could be observed in the corporate sector (consider the drying up of "big pharma" pipelines) which nevertheless also expropriated the relatively few younger, dynamic innovators such as the billion dollar turnover "unicorns".

Funding: This paper was presented as a keynote speech of SOItmC 2019, and the publishing fee was supported by SOItmC.

Conflicts of Interest: The author declares no conflict of interest.

\section{References}

1. Gross, B. Friendly Fascism; M. Evans and Company: Lanham, MD, USA, 1980.

2. Dick, P.K. "The Variable Man" The Collected Short Stories of Philip K. Dick, v.1: The Short Happy Life of the Brown Oxford (1987); Citadel: New York, NY, USA, 1952.

3. Galbraith, J.K. The Affluent Society; Penguinl: London, UK, 1961.

4. Bridle, J. New Dark Age: Technology and the End of the Future; Verso: London, UK, 2018.

5. Tooze, A. Crashed: How a Decade of Financial Crisis Changed the World; Allen Lane: London, UK, 2018.

6. Dick, P.K. Dictionary of Literary Biography: Twentieth Century American Science Fiction Writers; Cowart, D., Ed.; Gale: Columbia, SC, USA, 1981; Volume 8.

7. Schumpeter, J. The Theory of Economic Development; Transaction Books: New Brunswick, NJ, USA, 1934.

8. Schumpeter, J. Capitalism, Socialism, Democracy; Harper: New York, NY, USA, 1975. 
9. Stam, E. Entrepreneurial ecosystems and regional policy: A sympathetic critique. Eur. Plan. Stud. 2015, 23, 1759-1769. [CrossRef]

10. Mazzucato, M. The Value of Everything: Making and Taking in the Global Economy; Allen Lane: London, UK, 2018.

11. Dick, P.K. Man, Androids and Machine. In The Shifting Realities of Philip K. Dick 1995; ACE: New York, NY, USA, 1975.

12. Marshall, A. Industry and Trade; Macmillan: London, UK, 1919.

13. Becattini, G. Sectors or Districts: Some remarks on the conceptual foundations of industrial economics. In Small Firms \& Industrial Districts in Italy; Goodman, E., Ed.; Routledge: London, UK, 1989.

14. Porter, M. On Competition; Harvard Business School Books: Boston, MA, USA, 1998.

15. OECD. Business Dynamics \& Productivity; OECD: Paris, France, 2017.

16. Stiglitz, J. The Great Divide; Norton: New York, NY, USA, 2015.

17. Gordon, R. The Rise and Fall of American Growth; Princeton University Press: Princeton, NJ, USA, 2016.

18. Erixon, F.; Weigel, B. The Innovation Illusion: How So Little is Created by So Many Working So Hard; Yale University Press: New Haven, CT, USA, 2016.

19. Lindsey, B.; Teles, S. The Captured Economy: How the Powerful Enrich Themselves, Slow Down Growth, and Increase Inequality; Oxford University Press: Oxford, UK, 2017.

20. Foster, L.; Haltiwanger, J.; Krizan, C.J. Market selection, reallocation and restructuring in the US retail trade sector in the 1990s. Rev. Econ. Stat. 2006, 88, 748-758. [CrossRef]

21. Davis, S.; Haltiwanger, J. Labour Market Fluidity and Economic Performance, NBER, Working Paper No 20479; National Bureau of Economic Research, Inc.: Cambridge, MA, USA, 2014.

22. Decker, R.; Haltiwanger, J.; Jarmin, R.; Miranda, J. The role of entrepreneurship in US job creation and economic dynamism. J. Econ. Perspect. 2014, 28, 3-24. [CrossRef]

23. Decker, R.A.; Haltiwanger, J.; Jarmin, R.S.; Miranda, J. Where has all the skewness gone? The decline in high-growth (young) firms in the US, forthcoming. Eur. Econ. Rev. 2016, 86, 4-23. [CrossRef]

24. Decker, R.; Haltiwanger, J.; Jarmin, R.; Miranda, J. The Decline of High-Growth Entrepreneurship, 19 March 2016. Available online: https://voxeu.org/article/decline-high-growth-entrepreneurship (accessed on 3 April 2019).

25. Hecker, D. High-technology employment: A NAICS-based update. US Department of Labor and US Bureau of Labor Statistics. Mon. Lab. Rev. 2005, 128, 58.

26. Hurst, E.; Pugsley, B. What do small businesses do? Brook. Pap. Econ. Act. 2012, 43, 73-142.

27. Hathaway, I.; Litan, R. Declining Business Dynamism in the United States: A Look at States and Metro; Brookings Institution: Washington, DC, USA, 2014.

28. Fernald, J. Productivity and Potential Output before, during, and after the Great Recession. In NBER Macroeconomics Annual Vol. 29; Parker, J., Woodford, M., Eds.; University of Chicago Press: Chicago, IL, USA, 2014.

29. Roper, S.; Hart, D. State of Small Business Britain Report; Warwick-Aston, ERC: Birmingham, UK, 2018.

30. Bijners, G.; Konings, J. Where Has Belgian Business Dynamics Gone? The Decline in High Growth (Small) Firms. VIVES Working Paper 59. 2017. Available online: https:/ / feb.kuleuven.be/VIVES/publications / discussion_papers/dp2017/vives-discussion-paper-59-business-dynamism (accessed on 3 April 2019).

31. Aldrick, P. American Dream is Fading Away as Fewer Tap into Entrepreneurial Spirit. The Times, 3 July 2018; p. 42.

32. Aldrick, P. 100,000 Zombie Firms Suck Life Out of Economy. The Times, 7 December 2017; 43.

33. Brookings. Are the Self-Employed Happy Entrepreneurs? Brookings: Washington, DC, USA, 2017.

34. Tepper, J.; Hearn, D. The Myth of Capitalism: Monopolies and the Death of Competition; Wiley: New York, NY, USA, 2018.

35. Helpman, E. (Ed.) General Purpose Technologies and Economic Growth; MIT Press: Cambridge, MA, USA, 1998.

36. Fort, T.; Haltiwanger, J.; Jarmin, R.; Miranda, J. How Firms Respond to Business Cycles: The Role of Firm Age and Firm Size. NBER Working Paper No. 19134. 2013. Available online: https:/ /www.nber.org/papers/ w19134 (accessed on 3 April 2019).

37. Dick, P.K. The Three Stigmata of Palmer Eldritch; Doubleday: Garden City, NY, USA, 1964.

38. Morgan-Bentley, P. Criticism of May Banned in Grenfell Safety Deal. The Times, 7 November 2018. 
39. Weintraub, R. Neoclassical Economics. In The Concise Encyclopedia of Economics; Henderson, D., Ed.; The Liberty Fund: Indianapolis, Indiana, 2002.

40. Pavitt, K. Sectoral patterns of technical change: Towards a taxonomy and a theory. Res. Policy 1984, 13, 343-375. [CrossRef]

41. Pavitt, K. Chips and "trajectories": How does the semiconductor influence the sources and directions of technical change? In Technology and the Human Prospect; Maclean, R., Ed.; Pinter: London, UK, 1986.

42. Heiner, J. The origin of predictable behaviour. Am. Econ. Rev. 1983, 73, 56-70.

43. Knight. Risk, Uncertainty and Profits; Chicago University Press: Chicago, IL, USA, 1921.

44. Alchian, A. Uncertainty, evolution, and economic theory. J. Polit. Econ. 1950, 58, 201-221. [CrossRef]

45. Simon, H. The Architecture of Complexity. Proc. Am. Philos. Soc. 1962, 106, 181-201.

46. Simon, H. Theories of Bounded Rationality. In Decisions and Organisations; McGuire, C., Radner, R., Eds.; North-Holland Publishing Company: Amsterdam, The Netherlands, 1972.

47. Hahn, O. Equilibrium and Macroeconomics; Blackwell: Oxford, UK, 1984.

48. Rosenberg, N. Inside the Black Box; Cambridge University Press: Cambridge, UK, 1982.

49. Dosi, G. Sources, Procedures and Microeconomic Effects of Innovation. J. Econ. Lit. 1988, 26, 1120-1171.

50. Dick, P.K. A Scanner Darkly; Doubleday: New York, NY, USA, 1977.

51. Butler, S. High Streets Lose 85,000 Retail Jobs as Traders Feel the Pinch. The Observer, 11 November 2018; 35.

52. Rodrik, D. The Globalization Paradox: Democracy and the Future of the World Economy; Norton: New York, NY, USA, 2011.

53. Criscuolo, C.; Gal, P.; Menon, C. The Dynamics of Employment Growth: New Evidence from 18 Countries, OECD-STI; OECD: Paris, France, 2014.

54. St. Amant, P.; Tessier, D. Firm Dynamics and Multifactor Productivity: An Empirical Exploration; Bank of Canada: Ottawa, ON, Canada, 2018.

55. Deloitte Canada. Too Many Canadian "Zombie" Companies Drag down National Productivity; Deloitte: Toronto, ON, Canada, 2018.

56. McKinsey Global Institute. The Future of Japan: Reigniting Productivity \& Growth; McKinsey \& Company: New York, NY, USA, 2015.

57. Butcher, B.; Bursnall, M. How Dynamic is the Private Sector? Job Creation and Insights from Workplace-Level Data. Natl. Inst. Econ. Rev. 2013, 225, F4. [CrossRef]

58. Duffy, J. Zombie startups: Why are entrepreneurs failing to grow their businesses? The Guardian, 7 August 2017.

59. Kawasaki, G. The Art of the Start; Penguin: New York, NY, USA, 2004.

60. D'Onfro, J. Alphabet Reportedly had more Contractors than Direct Employees this Year. CNBC Tech, 25 July 2018.

61. Sheng, E. Silicon Valley's Dirty Secret: Using a Shadow Workforce of Contract Employees to Drive Profits. CNBC-Work, 22 October 2018.

62. Siilasmaa, R. Transforming Nokia; McGraw-Hill: New York, NY, USA, 2019.

(C) 2019 by the author. Licensee MDPI, Basel, Switzerland. This article is an open access article distributed under the terms and conditions of the Creative Commons Attribution (CC BY) license (http:/ / creativecommons.org/licenses/by/4.0/). 